\title{
Potential Development of Sustainable 3D-Printed Meat Analogues: A Review
}

\author{
Karna Ramachandraiah
}

Citation: Ramachandraiah, $\mathrm{K}$

Potential Development of Sustainable 3D-Printed Meat Analogues: A Review. Sustainability 2021, 13, 938 https://doi.org/10.3390/su13020938

Received: 11 December 2020

Accepted: 12 January 2021

Published: 18 January 2021

Publisher's Note: MDPI stays neutral with regard to jurisdictional claims in published maps and institutional affiliations.

Copyright: (C) 2021 by the author. Licensee MDPI, Basel, Switzerland. This article is an open access article distributed under the terms and conditions of the Creative Commons Attribution (CC BY) license (https:/ / creativecommons.org/licenses/by/ $4.0 /)$.
Department of Food Science and Biotechnology, College of Life Science, Sejong University, Seoul 05006, Korea; karna@sejong.ac.kr; Tel.: +82-2-6935-2465; Fax: +82-2-3408-4319

\begin{abstract}
To mitigate the threat of climate change driven by livestock meat production, a multifaceted approach that incorporates dietary changes, innovative product development, advances in technologies, and reductions in food wastes/losses is proposed. The emerging technology of 3D printing (3DP) has been recognized for its unprecedented capacity to fabricate food products with intricate structures and reduced material cost and energy. For sustainable 3DP of meat substitutes, the possible materials discussed are derived from in vitro cell culture, meat byproducts/waste, insects, and plants. These material-based approaches are analyzed from their potential environmental effects, technological viability, and consumer acceptance standpoints. Although skeletal muscles and skin are bioprinted for medical applications, they could be utilized as meat without the additional printing of vascular networks. The impediments to bioprinting of meat are lack of food-safe substrates/materials, cost-effectiveness, and scalability. The sustainability of bioprinting could be enhanced by the utilization of generic/universal components or scaffolds and optimization of cell sourcing and fabrication logistics. Despite the availability of several plants and their byproducts and some start-up ventures attempting to fabricate food products, 3D printing of meat analogues remains a challenge. From various insects, powders, proteins (soluble/insoluble), lipids, and fibers are produced, which-in different combinations and at optimal concentrations-can potentially result in superior meat substitutes. Valuable materials derived from meat byproducts/wastes using low energy methods could reduce waste production and offset some greenhouse gas (GHG) emissions. Apart from printer innovations (speed, precision, and productivity), rational structure of supply chain and optimization of material flow and logistic costs can improve the sustainability of 3D printing. Irrespective of the materials used, perception-related challenges exist for 3D-printed food products. Consumer acceptance could be a significant challenge that could hinder the success of 3D-printed meat analogs.
\end{abstract}

Keywords: 3D printing; meat analogs; sustainability; environmental impact

\section{Introduction}

Climate change is a growing concern amongst several nations around the world. The discernable impact of human-induced climate change include increases in temperature, the frequency of droughts, rainfall intensity, flooding, and other severe weather events. Climate change has also been projected to affect all facets of food security, which include availability, ease of access, consumption, and stability [1-3]. The amount and rate of climate change are mainly affected by greenhouse gas (GHG) emissions that result from energy generation (fossil fuel combustion) and non-energy emissions (agriculture, land-use changes, and livestock production) [1]. However, the contribution from the livestock sector to the total annual anthropogenic GHG emissions is about 14.5\% [4]. Major livestock that contribute to this threat are cattle, pigs, sheep, goats, and chickens [5,6]. Beef is the most problematic of all livestock because it requires large land areas and resources [5,7]. Of the total anthropogenic $\mathrm{CH}_{4}, \mathrm{~N}_{2} \mathrm{O}$, and $\mathrm{CO}_{2}$ emissions, the livestock sector contributes $19 \%, 15 \%$, and $1.35 \%$, respectively [4]. The direct and indirect effects of livestock production include 
food security issues, health risks, animal welfare issues, and the loss of biodiversity [8]. Apart from the impact of GHG from meat production, ethical issues pertaining to the slaughter of animals are strong reasons to seek alternatives for livestock meat. As a result, some strategies have been proposed that include dietary changes, innovative products, technological improvements, and diminutions in food wastes and losses [9].

A well-known strategy in dietary change is meat substitution through plant materials such as soy and peas [10]. Another strategy is lab meat or cultured meat production, wherein animal muscle cells are derived from tissue cultures [11]. Other sources of materials such as insects and mycoproteins have also been considered for the development of meat analogs [10]. Even though the market share of plant-based meat analogs is relatively low, the global protein analog market is expected to reach $\$ 7.5$ billion USD around the year 2025 [12]. However, in order to counter the negative impact of livestock production, a multidimensional strategy, which includes novel plant materials-derived alternatives, enhanced waste management, and policy restructurings, has been proposed $[9,13]$. In this regard, $3 \mathrm{D}$ printing (3DP) is a promising technology that can sustainably fabricate customizable products with intricate shapes and textures.

The 3D printing process involves a layer-by-layer deposition of materials (inks) to form $3 \mathrm{D}$ complex intricate structures [14]. The 3DP technology is suggested to have a significant potential to lower $\mathrm{CO}_{2}$ emissions and lifecycle energy demands of manufacturing products. The global 3DP market is expected to expand to $\$ 230-550$ billion USD by the end of $2025[15,16]$. In this review, 3D-printing-based approaches for the fabrication of meat substitutes are explored. The four main 3D printing approaches are based on the materials that are derived from in vitro cell culture (muscle cells), meat byproducts/wastes, insects, and plants (Figure 1). While there are many studies that have focused on 3D printing of food products, which include meat, the studies on the use of 3D printing of meat analogs are very limited. Thus, this review focuses on the four main 3DP approaches from the standpoints of technological feasibility, the effect on the environment, and consumer acceptance.

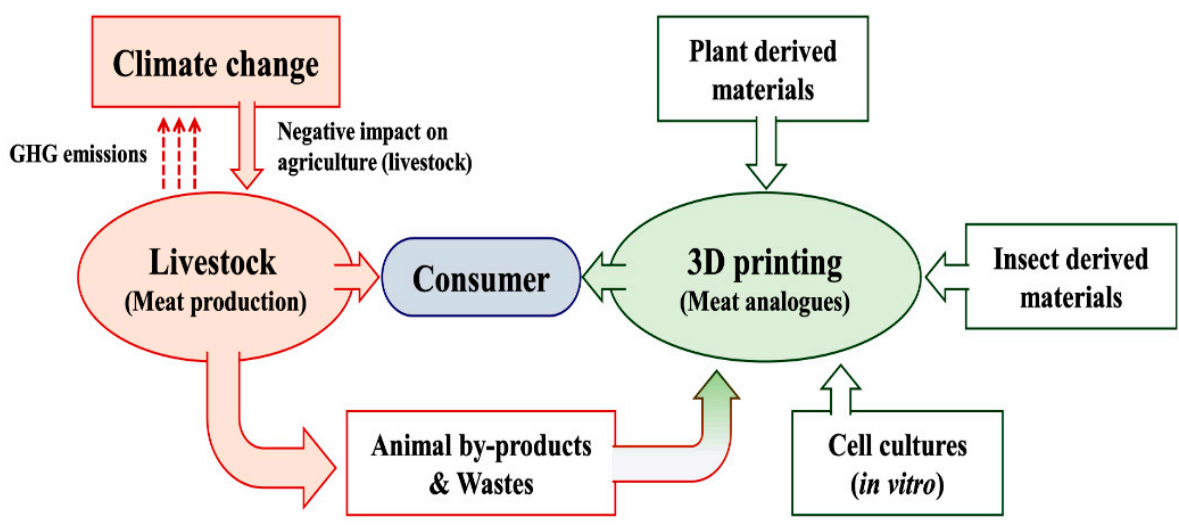

Figure 1. Schematic illustration of 3D printing (3DP) of meat analogs and its impact on climate change.

\section{Overview of 3D Printing Technology}

The 3DP technology, which is also known as fused deposition modeling (FDM), is a major type of additive manufacturing (AM) that includes other types, such as selective laser sintering (SLS) and stereolithography (SL) [17]. For 3D printing, a variety of materials exist that include polymers, metals, ceramics, and biomaterials. This type of AM has been identified as a promising manufacturing process in various industries that include the food industry [18]. This relatively new technology evolved in the mid-80s due to advances made in computing and control systems [19]. The 3DP technology consists of a digital manufacturing machine that fabricates three-dimensional objects based on designs created by a computer-aided design/manufacturing (CAD/CAM) software [20,21]. As shown in Table 1, the common methods of 3DP are extrusion, inkjet printing, binder jetting, and bioprinting $[19,22]$ Meat products are typically printed by an extrusion process, 
wherein fibrous meat materials are extruded from a nozzle in order to form 3D structures. Even though other methods are under development, the extruder type, which includes a screw conveyor or syringe system that can also control the temperature, holds great promise for the 3D printing of meat products with the desired design [14]. In this method, materials are extruded in a layer-by-layer fashion via a nozzle for the geometric 3D structures. Furthermore, extrusion usually involves the use of semi-solid pastes, such as doughs, chocolates, and meat purees. In the case of inkjet printing, liquid materials that have low viscosity are dispersed in a continuous jet or by using a drop-on-demand method to form liquid foods. The binder jetting commonly employs powders (e.g., cocoa and sugar) to form 3D structures. Although bioprinting is under development, it is also accomplished through the usual three major methods-jetting, lasers, and extrusion [23]. In the jetting methods, bio-ink droplets are formed electrostatically or piezo-electrically by an inkjet printer head that is placed over the printing bed. In laser methods, cells are deposited on matrices using lasers. Lastly, in the extrusion system, the bio-ink is deposited through a syringe and piston system, which extrudes the material in a layer-by-layer manner. Bioprinting has gained attention due to its promising scope in the area of tissue engineering [23].

Table 1. Major types of 3D printing for meat analogs.

\begin{tabular}{|c|c|c|c|c|}
\hline & Extrusion & Inkjet Printing & Binder Jetting & Bioprinting \\
\hline Merits & $\begin{array}{l}\text { Availability of several } \\
\text { materials, simple device }\end{array}$ & $\begin{array}{l}\text { Availability of several } \\
\text { materials, relatively } \\
\text { improved printing and } \\
\text { fabrication rate }\end{array}$ & $\begin{array}{l}\text { Possibility of printing } \\
\text { complex 3D structures }\end{array}$ & $\begin{array}{c}\text { Printing of tissue analogs } \\
\text { utilizing living cells }\end{array}$ \\
\hline Demerits & $\begin{array}{l}\text { Lack of superior intricate } \\
\text { 3DP products }\end{array}$ & $\begin{array}{c}\text { Preferable for } \\
\text { simple designs }\end{array}$ & $\begin{array}{l}\text { Lack of availability of a } \\
\text { wide variety of materials }\end{array}$ & $\begin{array}{c}\text { Lack of food-safe } \\
\text { materials }\end{array}$ \\
\hline $\begin{array}{l}\text { Processing } \\
\text { Factors }\end{array}$ & $\begin{array}{l}\text { Height of fabricated } \\
\text { products, size of nozzle } \\
\text { diameter, printing rate, } \\
\text { rate of nozzle motion }\end{array}$ & $\begin{array}{c}\text { Speed of printing, size of } \\
\text { nozzle diameter, Height } \\
\text { of fabricated products, } \\
\text { temperature }\end{array}$ & $\begin{array}{l}\text { Speed of printing, nozzle } \\
\text { diameter, thickness of } \\
\text { fabricated layers, } \\
\text { Head types }\end{array}$ & $\begin{array}{c}\text { layer-by-layer assembly } \\
\text { of multiple layers, } \\
\text { requirement of } \\
\text { multi-materials }\end{array}$ \\
\hline
\end{tabular}

Adapted from Liu et al. [24].

\section{Technological Feasibility of Meat Analog Fabrication}

The development of meat substitutes is contingent upon mimicking the taste, texture, appearance, and nutritional values of conventional (livestock) meat. Amongst these features, recreating a meat-like texture is considered to be the most challenging [25]. Even 3DP of conventional meat has been recognized to be demanding due to the fibrous make-up of meat, which is derived mostly from the muscles of animals (livestock). Moreover, 3DP of food products is limited due to the lack of suitable materials and the difficulty of integrating it into traditional foods [26]. To overcome these challenges, two major strategies have been suggested: (a) product reformulation [26] and (b) printer innovation [27]. Figure 2 illustrates the major materials available for product reformulation, which can be achieved via two approaches-modifying formulations (recipes) or including additives. Modification of materials can be seen in the case of meat (raw), which is ground into a paste (particle size optimization) for smooth extrusion from the nozzle. This is performed to reduce the particle sizes of ingredients less than the size of the printer nozzle ( $\mathrm{mm}$ to $\mu$ ) in order to prevent clogging [14]. To improve printability, additives can also be included. For example, a plasticizer such as gelatin was included in the meat slurries made of chicken, pork, and fish. In another study, turkey meat, mixed with bacon fat and transglutaminase (TGase), was 3D printed and then subjected to sous-vide cooking [26]. Sous-vide is a cooking technique wherein vacuum-packed food is cooked at a precisely controlled temperature. In regards to the meat analogs, a wide variety of materials exists for use in the 3DP process. Some commonly used plant materials include soy, wheat, peas, and fungi. Similarly, insects can also be used to form 3D-printed meat analogs. In one study, dried yellow mealworms were milled to form a powder that was mixed with cereal flours, which 
in turn was printed [28]. Biomolecules, such as proteins, fats, and fibers isolated from insects, can also be used as building blocks. Crosslinking proteins can potentially be used to construct novel foods. Other materials, such as mushrooms, fruit, and vegetables, have also been 3D printed [29]. In the case of bioprinting, 3D structures are constructed with bio-inks, which contain cells, biomaterials, and other molecules [30]. The cell contained in bio-inks typically ranges between 10,000 to 30,000 per droplet $(10-20 \mu \mathrm{L})$. The cell's suspended medium that is activated via photo/thermal processes mainly contains polymer crosslinkers, such as $\mathrm{CaCl}_{2}$, thrombin, salt $(\mathrm{NaCl})$, gelatin, and fibrinogen [20]. Biomaterials, such as melt-cure polymers, hydrogels, or decellularized extracellular matrix (dECM), are utilized in bio-inks to provide an appropriate microenvironment for the adhesion of cells and their migration and differentiation [30]. However, regardless of the input material, the final 3D product has to be a meat analog that is consumed instead of meat. 3DP snacks, such as cookies and cakes cannot be considered as a meat analogs, even when the ingredients were derived from meat byproducts or insects.

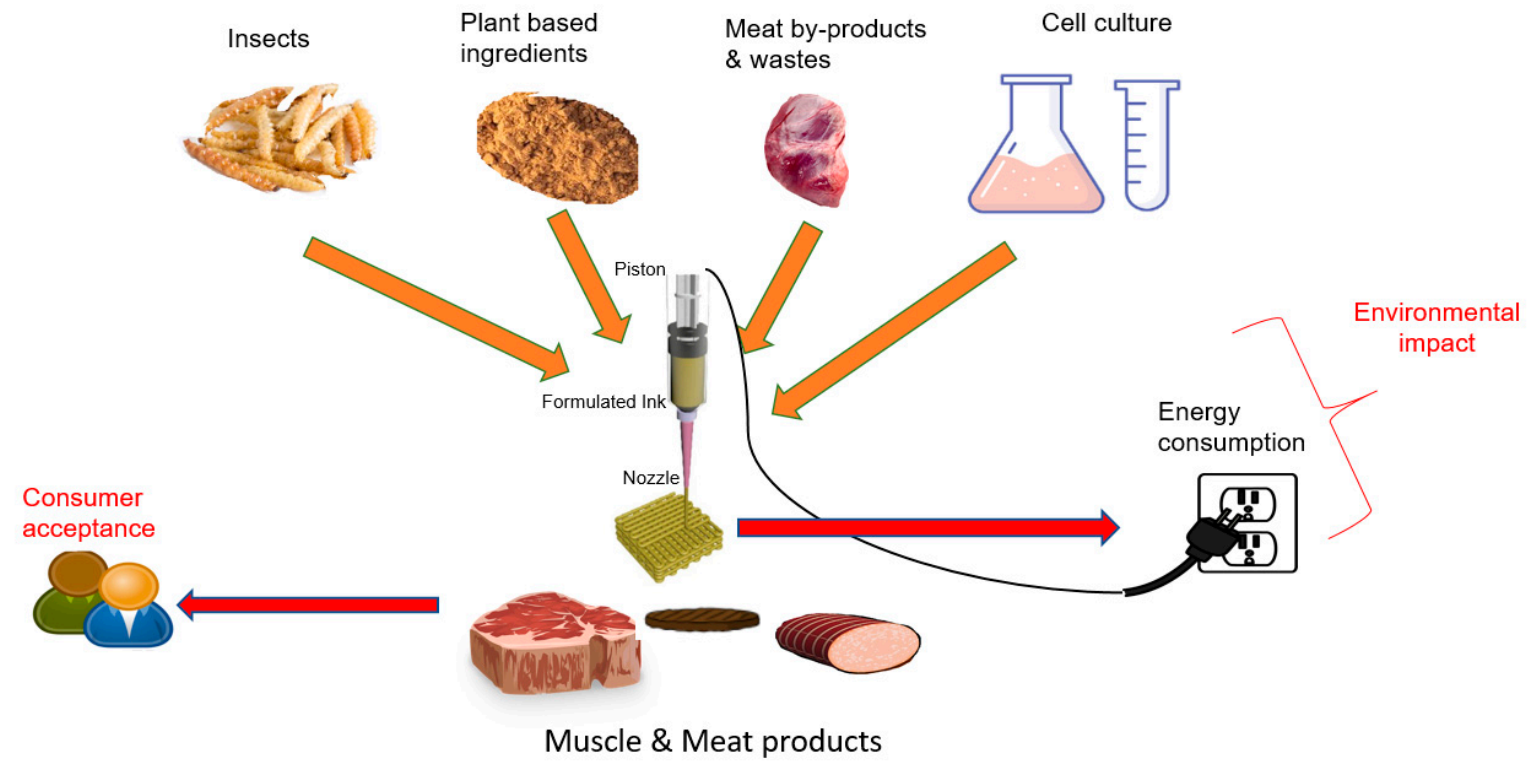

Figure 2. Utilization of major biomaterials for the development of 3D printing (3DP) of meat analogs. Adapted from [31].

Printer-innovation-related challenges also exist for 3DP of food products. The main technological considerations for $3 \mathrm{DP}$ are the $3 \mathrm{D}$ positioning process and the dispensing system. The positioning system is controlled by design/manufacturing software (CAD) that aid in the creation of 3D structures. In the case of bioprinting, it is accomplished using multiple heads (generally), which also require several sensors to ensure the thickness of each layer. Nevertheless, errors can occur when layer-by-layer printing is involved. Thus, to overcome this challenge, printer heads attached with a video camera, fiberoptic light, heat regulator, and piezoelectric humidifiers have been recommended [20]. While the fiber optic light can illuminate and cure the constructed layer, heat regulators along with piezoelectric humidifiers are able to inhibit the polymerization of materials in the printer head. With respect to the dispensing system, the most common is the extruder type, which can have a single or a double nozzle [14]. However, in bioprinting, the type of nozzle and printer head depends on the bio-inks being used [20]. Furthermore, different operational settings may be required depending on the type of material such as insects, meat byproducts, fibers from muscle cells, and plants. For example, meat byproducts may require temperatures that are less than $4^{\circ} \mathrm{C}$ for the inhibition of microbial growth. However, the major demerits associated with the feasibility of 3DP are the products' time-consuming 3D design process, limited precision, and low productivity (Figure 3) [27]. The designing of $3 \mathrm{D}$ products such as meat analogs can also be complex and time-intensive. Moreover, wide 
ranges of meat products (traditional foods) are available in the market. A few examples of freshly processed meat products include sausages, patties, and bratwurst. Some other types of products are cured meat cuts, frankfurters, fermented products, and dried meat products such as jerky and biltong [32]. Therefore, a database of different structures has to be prepared, maintained, and be easily available. The precision is also a major demerit because the final products (raw and final) can undergo post-processing. In particular, meat analogs may undergo a post-processing step such as boiling and frying that has to be performed separately. This must be considered for the large-scale production of $3 \mathrm{D}$ products. Finally, the productivity of $3 \mathrm{D}$ printing is dependent on the speed and throughput (number of products) of a printer [27]. Thus, smaller (benchtop) printers that use hybrid printing at high speeds via multiple nozzles are more desirable than several large printers.

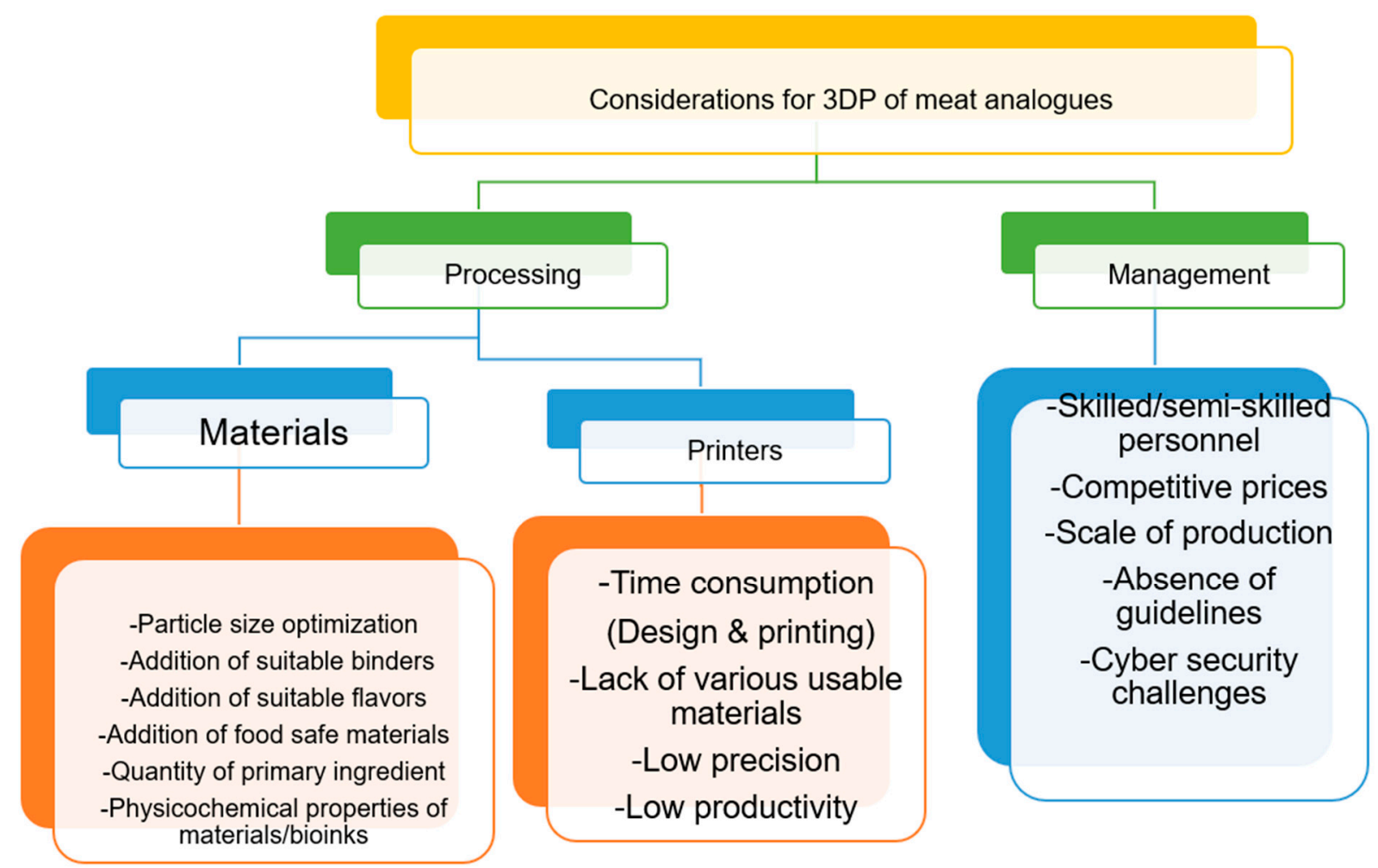

Figure 3. Technological consideration for the 3D printing (3DP) of meat analogs. Adapted from [33].

\section{Materials-Based 3DP Approaches}

With the 3D printing of meat analogs, the ease of printability depends on the materials utilized. Thus, four major types of materials have been identified, which include biomaterials (bio-driven), native materials, non-native materials, and alternative materials $[14,26]$.

\subsection{Biomaterials-Based 3DP: Bioprinting}

The utilization of biomaterials for the 3D printing of complex structures such as muscles, skin, bones, and cartilage is known as bioprinting [34]. This technology involves the precise arrangement of bio-inks (different cell types, biomaterials, and growth factors) within a single structural framework [35]. The selection of cells (progenitor cells or stem cells) is contingent upon the main purpose of the application [36]. The printing of spatial patterns of living cells can be achieved via three major manufacturing concepts-direct printing, indirect printing, and hybrid printing. Direct printing involves bioprinting inks such as cell-laden hydrogels. Indirect printing encompasses the printing of cell-laden 
hydrogel layers onto a sacrificial component or mold that is cell-free. A third and better concept is hybrid printing, which is a combination of different methods [23,36]. Although tissue structures, such as bone, cartilage, tendon, skin, and muscle have been 3D printed for tissue engineering applications, only skeletal muscles can be considered for the production of meat. Skeletal muscles primarily contain muscle fibers along with connective tissues and intramuscular adipose tissues [37]. In recent times, the development of human muscle tissues that mimic the native muscle tissues of humans has gained attention, particularly in reconstructive surgery [38]. Bioengineered muscles, which are similar to native muscle tissues, are formed by methods (e.g., in vitro culture, electrospinning) that mainly focus on the uniaxial alignments of muscle cells [25,35]. In this regard, 3D printing is being used to fabricate muscles that are structurally and functionally similar to native tissues [38]. In one study, skeletal muscle was 3D printed using three major components: (a) hydrogel bioink that contained human muscle progenitor cell (hMPC), (b) sacrificing acellular gelatin hydrogel bio-ink, and (c) supporting poly ( $\varepsilon$-caprolactone) (PCL) polymers [38]. More recently, vascularized tissues have been $3 \mathrm{D}$ printed, which is considered to be a technical challenge [23]. Furthermore, integrated tissue-organ printing (ITOP) system, which can use various cell types and biomaterials, has been adopted to fabricate vascularized human-scale tissues [39]. Although these methods are used for bioprinting human muscles, they can be adopted for the fabrication of animal muscles. This is because farm animals have similar body sizes to humans, and their development patterns of adipose tissue and skeletal muscles are also closer to humans [37]. Table 2 shows some examples of 3DP human skeletal muscles. However, for the fabrication of meat, complex blood vessel (vascular) systems are not essential. While a less complicated perfusion system or channel seems adequate, the precise contribution of blood vessels on the organoleptic properties of meat has yet to be investigated [40].

Table 2. Some examples of 3D bioprinted human skeletal muscles.

\begin{tabular}{|c|c|c|c|c|c|}
\hline $\begin{array}{l}\text { Printing } \\
\text { Technique }\end{array}$ & Materials & Cell Types & $\begin{array}{l}\text { Printing } \\
\text { Parameter }\end{array}$ & Features & References \\
\hline Extrusion & $\begin{array}{c}\text { dECM } \\
\text { PCL contraints } \\
\text { Gelatin }\end{array}$ & $\begin{array}{l}\text { Human skeletal } \\
\text { muscle cell }\end{array}$ & Temp: $18^{\circ} \mathrm{C}$ & $\begin{array}{l}\text { Mimicking native } \\
\text { muscle } \\
\text { Vascularization }\end{array}$ & [41] \\
\hline Extrusion & $\begin{array}{c}\text { CMCMA, } \\
\text { Alginate-MA }\end{array}$ & $\mathrm{C} 2 \mathrm{C} 12$ & $\begin{array}{l}\text { Nozzle size: } \\
200 \text { micron }\end{array}$ & $\begin{array}{l}\text { Mechanical } \\
\text { property } \\
\text { optimization }\end{array}$ & [42] \\
\hline ITOP & $\begin{array}{c}\text { Fibrinogen } \\
\text { gelatin HA, glycerol, } \\
\text { PCL pillar }\end{array}$ & hMPCs & $300 \mu$ width & $\begin{array}{l}\text { Increased cell } \\
\text { viability }\end{array}$ & [35] \\
\hline ITOP & $\begin{array}{l}\text { Gelatin hydrogel } \\
\text { poly ( } \varepsilon \text {-caprolactone) } \\
\text { (PCL) polymer }\end{array}$ & hMPCs & $300-400 \mu$ & $\begin{array}{c}\text { highly viable, } \\
\text { organized cellular } \\
\text { structure }\end{array}$ & [38] \\
\hline
\end{tabular}

Notes, Adapted from [34]. dECM, decellularized extracellular matrix; PCL, polycaprolactone; CMCMA, carboxymethyl cellulose-methacrylate; $\mathrm{MA}$, alginate-methacrylate; HA, hyaluronic acid; $\mathrm{C} 2 \mathrm{C} 12$, myoblast cell line; and hMPCs, human primary muscle progenitor cells.

The bioprinting of tissues and organoids is mainly based on bio-inks. The development of bio-ink, a medium that contains living cells along with crosslinkers, is considered to be challenging [20]. However, for the development of meat analogs, it becomes important that food-safe culture substrates be utilized for animal cell culture. In general, bio-inks lacking in living cells are used as a scaffold (e.g., hydrogel-based) for the culture and growth of cells [20]. In the case of meat analogs, apart from being in scales that are appropriate, the scaffolds used have to be composed of edible materials [43]. While there are some synthetic hydrogels (e.g., poly(N-(2-hydroxypropyl) methacrylamide lactate $(\mathrm{PH}-$ PMA) and polyethylene glycol (PEG)) for the fabrication of scaffolds, natural polymers (e.g., agarose, alginate, gelatin, chitosan) [44] may be used for the 3DP meat analog. Other natural polymers such as fibrinogen and collagen have also been used as scaffolds to im- 
prove the tissue stiffness and the physiological resemblance to in vivo skeletal muscles [45]. Although multiple layers can easily be printed with collagen, they tend to lose shape due to dissolution or swelling. To counter this problem, other biodegradable materials have to be added [20]. Most importantly, the choice of hydrogel is based on principles such as cross-linking mechanism, ionic interactions, and colloidal chemistry [36]. However, the use of hydrogel is also not without problems. While high concentrations of hydrogels can improve printability, they can also cause lower cell viability. Thus, a combination of hydrogels with low concentrations has been suggested. Owing to such demerits, a new type of bio-ink, decellularized extracellular matrix (dECM), has gained attention. This bio-ink provides an appropriate environment for myotube formation and differentiation. The printability of skeletal muscle, adipose, heart tissue, and cartilage has indicated the feasibility of bioprinting with $\mathrm{dECM}$. However, the lack of superior shape fidelity of post-printed structures has been recognized to be a challenge [30].

For the improvement of the surface morphology of 3D scaffolds used for tissue engineering, 3D-printed scaffolds have been coated with electrospun nanofibers. In a study, short poly(lactic-co-glycolic acid) (PLGA)-collagen-gelatin (PCG) nanofibers enhanced the linkage and proliferation of stem cells (bone marrow mesenchymal stem cells (BMSCs)) [46]. However, it is not necessary to have scaffolds for the fabrication of skeletal muscles. In one study, the monolayer-cultured rat muscle cells were rolled to form cylindrical shape structures for the fabrication of muscles [47]. It is noteworthy to mention that in the aforementioned studies, the 3DP muscles possessed the functional properties of natural muscles in humans. However, when the muscles are developed from animal cells for meat, their functional properties are not that important. It was reported that companies such as Modern Meadow ${ }^{\mathrm{TM}}$ (Brooklyn, New York, U.S) had attempted to fabricate meat using fat and muscle cells. Recently, this company has not been making any meat products, and it is involved in the production of leathers [48]. However, the cost-effectiveness of 3DP muscles is an important factor that determines its commercial success. According to a study, even though the FDM and the laser sintering (LS) are both considered scalable and reproducible processes, FDM is reported to be more cost-effective. Apart from machine cost, the printing material cost ( $£ 30$ per $\mathrm{kg}$ ) was found to be lower for the FDM technique compared to LS $(\sim £ 200$ per $\mathrm{kg})$ [45].

\subsection{Native Printable Materials}

Native printable materials possess the ability to flow easily from a nozzle, which thereby does not require any additional flow enhancers. Some major samples of native printable materials that have been 3D printed include dough, chocolate, and puree. Moreover, for some of the native printable materials, it is not necessary to undergo postprocessing, which could impact the structure of the final product [16].

\subsection{Non-Native Printable Materials}

Non-native materials need flow enhancers for the proper extrusion of food materials (e.g., meat, fish, seafood, fruits). The non-native printing of meat was first reported by [26] In their study, turkey meat with added transglutaminase (TGase) and pork fat was 3D printed for sous-vide cooking [26]. However, the maintenance of a proper 3D shape and structure throughout the cooking process is considered to be challenging. In particular, meat and seafood are subjected to post-processing treatments such as boiling or frying. Contrarily, products such as chocolate and cheese do not undergo these types of postprocessing operations $[14,26]$. In one study, the addition of gelatin to a meat slurry led to an improvement in the viscosity of pork, chicken, and fish meat. [24]. Likewise, in another study, canned tuna blended and mixed with spring water was 3D printed to form food for persons that have problems swallowing [49]. However, the lack of suitable food formulations and processing limitations deter the development of 3D printed products. Thus, 3D printing of meat, which is a complex matrix with diverse properties remains a challenge [14]. Although the aforementioned studies have utilized livestock meat as the 
main ingredient, it is very likely that similar methods can be employed for 3D printing of mimic meat products using materials derived from meat byproducts.

\subsubsection{Meat-Byproducts-Based 3D Printing}

To reduce the negative impact of livestock meat on the environment, the utilization of meat waste and byproducts has been suggested [14,50,51]. Meat production is known to result in inevitable wastes that mainly contain offal (body parts apart from muscles) and processing streams (wastewater, exudates, or brine solutions) [52,53]. Livestock byproducts, such as intestines, skin, feet, and fat, represent about $52 \%$ and $66 \%$ of the cattle live weight and the pig live weight, respectively. Since greater than half of these animals' live weight is rendered unfavorable for regular consumption, it becomes important to develop processes or technologies for the effective utilization of meat byproducts [54]. Furthermore, the large-scale disposal of meat byproducts and wastes in landfills raises environmental concerns. However, the re-utilization of byproducts for consumption also entails several challenges that include negative consumer perception and stringent regulation $[53,55]$. In this regard, their reuse in 3D printing could improve their environmental sustainability. In addition, this novel technology could also de-animalize animal byproducts (e.g., heart, liver, kidney, intestines, and tongue). De-animalization refers to the modification of food structures, such as the elimination of skin and bones, through which in that way reduces disgust reactions [56].

Apart from amino acids, vitamins, and fatty acids, some byproducts such as livers and kidneys also contain higher amounts of carbohydrates. Skin, ears, and feet are mostly composed of collagen, and their protein content is similar to lean meat. Amongst the byproducts, pork tail has been reported to contain the highest fat content but a lower water content. Owing to a large number of connective tissues, the amino acid composition of animal byproducts varies significantly compared to lean meat. According to the USDA, meat must contain a minimum of $14 \%$ protein and fat up to $30 \%$ for deboning [54]. In addition, wastes generated by meat-processing units mainly comprise processing streams, which can provide valuable proteins. However, the technical conditions for extraction of protein or peptides from meat byproducts/wastes are ease of extraction (non-denatured protein), lack of unfavorable compounds (colorants or flavors), and acceptable amino-acid profile [53]. Studies have reported that mechanically separated meat (MSM) such as surimi and chicken is commonly used as a major component in some processed meat products with low shelf life $[57,58]$. Table 3 shows the proximate analysis of a few meat-byproducts along with MSM. However, MSM added with transglutaminase (Tgase) could be used for 3D printing meat products, as discussed in an earlier section. In an investigation by Wang et al. [59], it was reported that the addition of salt to surimi gels $(1.5 \mathrm{~g} \mathrm{NaCl} / 100 \mathrm{~g}$ surimi mixture), improved its printability. Fish bone powder (nano-size), another fish byproduct that has a high calcium content, could also be added to MSM to enhance the endogenous TGase activity, leading to improved structures [60]. In another study, proteins derived from MSM (chicken) and pork lungs were reported to possess high gel strength [61]. Improved gel strength is considered to be an important functional property of ingredients in 3DP. Th 3D structures fabricated with stronger gel patterns are able to withstand their own weight throughout the printing process [59]. Furthermore, these proteins (mechanically separated chicken meat (MSCM) and pork lungs) have shown low gelation temperature $\left(\sim 45^{\circ} \mathrm{C}\right)$ and superior emulsifying properties, which make them suitable for various cooked meat products [61].

Apart from the aforementioned offal, as a replacement of porcine meat, proteins salvaged from four dissimilar processing streams and co-products (brine solution, stick water, exudates, blood plasma) were added to the Irish breakfast type sausages [62]. Thus, meat industrial wastes also offer a variety of biomolecules that could be used in the fabrication of 3D meat products. However, the production of biomolecules from byproducts is commonly achieved via traditional methods-enzymatic and thermal processes, solvent extraction, and fermentation [63]. Furthermore, to ensure the safety of byproducts, freezing 
(e.g., $-12{ }^{\circ} \mathrm{C}$ ) and packaging have to be employed. These are undertaken to control the growth of pathogens, such as Staphylococcus aureus, Clostridium perfringens, and Escherichia coli. All these have to be considered when meat-products are utilized as sources of 3D printing ingredients. Traditionally, byproducts are fried, roasted, boiled, smoked, and microwaved, which result in improved safety and characteristic flavors [64]. Hence, the effect of various offal derived materials and different post-processing methods on the physicochemical and sensory properties of 3D products has yet to be analyzed.

Table 3. Proximate analysis of a few meat byproducts and mechanically separated meat (MSM).

\begin{tabular}{cccc}
\hline $\begin{array}{c}\text { Meat } \\
\text { By-Products }\end{array}$ & Protein (\%) & Moisture (\%) & Fat (\%) \\
\hline Pork lungs & 16.6 & 79.1 & 2.1 \\
Pork kidneys & 16.2 & 77.7 & 4.0 \\
Chicken viscera & 11.2 & 69.6 & 16.9 \\
Mechanically separated meat (MSM): Chicken & 13.9 & 69.1 & 15.1 \\
\hline
\end{tabular}

Adapted from Rivera et al. [58].

Likewise, fish industrial waste also contains valuable biomaterials such as chitosan, amino acids, enzymes, and gelatin, which could be exploited [54]. According to a review, fish byproducts contain about $15 \%-30 \%$ of protein (crude), a maximum of $25 \%$ fat (crude), and $50 \%-80 \%$ moisture. Table 4 shows the proximate analysis of a few types of fish industrial wastes [65]. Collagen can also be derived from fish skin, which is discarded along with other parts (e.g., tails, gut, fins, and head), leading to marine pollution. In an investigation, the collagen extracted from eel skin was mixed with alginate hydrogel to form cost-effective and eco-friendly 3D constructs [66]. In one study by Yang et al. [67], in vitro $3 \mathrm{D}$-printed cartilage tissues were constructed using bio-inks that contained collagen type I (COL) or agarose (AG) combined with sodium alginate (SA). The cartilage bioprinted with SA/COL had better mechanical strength than the one bioprinted with SA/AG. Although the aforementioned $3 \mathrm{D}$ constructs were designed for tissue engineering, it is likely that materials derived from meat byproducts could be used for 3DP meat analogs. In addition, skin can also be printed with materials derived from meat byproducts. In an earlier study, shape fidelity issues of collagen and alginate-based 3DP multilayered skin (co-cultured with keratinocytes and fibroblasts) were countered with a cryogenic plotting system. In this technique, the collagen solution was deposited (layer-by-layer) at a temperature of $-40^{\circ} \mathrm{C}$ followed by freeze-drying at $-76{ }^{\circ} \mathrm{C}$ for three days [68]. In a recent study, a tissueengineered meat analog was developed using microfibrous gelatin, which acted as support for bovine muscle cells. The jet spun microfibers were fabricated using gelatin that was derived from animal wastes [43]. Thus, animal byproducts offer various biomaterials that could be utilized for 3DP, thereby lowering the environmental impact.

Table 4. Proximate analysis of fish industry wastes.

\begin{tabular}{cccc}
\hline $\begin{array}{c}\text { Composition (Nutri- } \\
\text { ent/Biomolecule) }\end{array}$ & Head & Flesh & Viscera \\
\hline Crude protein & $9-21 \%$ & $14-22 \%$ & $18-23 \%$ \\
Crude fat & $1-6 \%$ & $2-5 \%$ & $2-7 \%$ \\
Moisture & $59-68 \%$ & $70-77 \%$ & $64-72 \%$ \\
Ash & $7-18 \%$ & $2-5 \%$ & $2-5 \%$ \\
\hline
\end{tabular}

Adapted from Nawaz et al. [65].

\subsubsection{Plant-Materials-Based 3D Printing}

Plant-based meat replacers or substitutes are commonly derived from a wide range of materials that are mainly procured from cereals (e.g., barley and rye), legumes (e.g., mung beans, common beans, and lentils), and oilseeds such as cottonseed and rapeseed [69]. However, despite the development of some innovative plant-based meat analogs, widespread 
replacement of livestock meat has yet to happen. The lack of replacement is attributed to several causes, which mainly include consumer perception and cost [70]. As a result, several recent studies have focused on various types of plant materials for the development of meat analogs. In this regard, researchers have focused on pea protein because it has the ability to offer complementary functions to other constituents owing to its unique attributes [71,72]. However, the gelling capacity of pea protein has been reported to be lower than soy protein, thereby requiring salt addition or particle size modification. On the other hand, soy, which is commonly used, does not need to have high purity for the development of meat analogs. This is due to the presence of several constituents that enhance its water-holding capacity, gelling, and fat-absorbing properties. Another plant material that has gained attention is wheat, which can result in fibrous proteinaceous structures due to its capacity to form disulfide protein linkages [72]. This widely used material has been shown to improve the rheological and viscoelastic properties of analogs [69]. It is reported that high heat or pressure treatment of rapeseed proteins can improve the structure of meat analogs [72]. Lipid ingredients such as vegetable oils (e.g., sunflower oil and canola oil) that provide juiciness and flavor have also been used for the development of meat analogs [71]. While there are numerous materials derived from plants, aggregation of fibrous networks can clog the printer nozzle and lead to structures that have layer definitions [18,73]. Furthermore, several types of hydrocolloids may have to be incorporated for 3D printing of meat products. Some examples of hydrocolloids include xanthan gum, alginate, gum arabic, and carrageenan [18]. Nano-scaled materials such as cellulose nanofiber (CNF) can also potentially be used for 3DP. Studies have shown that the inclusion of CNF in pastes resulted in improved shape stability of 3D structures along with decreased clogging of tips [73].

The 3D printing of food products with complex matrices such as meat is considered to be challenging. The task of fabricating meat substitutes that mimic meat products with only plant materials is even more challenging. In particular, start-up ventures, namely, Beyond Burger and Impossible Foods, have taken up this challenge and have produced plant-based meat alternatives. Although Impossible Foods (Redwood City, California, US) uses various plant-based constituents, soy leghemoglobin is chiefly utilized for the development of the characteristic meat color, which is because of the pigment protein myoglobin. On the other hand, Beyond Burger (El Segundo, California, US) utilizes beet juice extract, while another startup has made use of tomato paste [71]. Other natural pigments such as red peppers, paprika, annatto, and red rice can also potentially be used [60]. In regards to 3D printing, a start-up called NOVAMEAT (Barcelona, Spain) has claimed to have fabricated 3D-printed beef and chicken. In 2018, this Barcelona-based company claimed to have printed steak using ingredients such as pea, seaweed, and beetroot juice. The 3D-printed steak was reported to be organoleptically similar to regular beef steak. The printed fibers had diameters in the range of $100 \mu$ to $500 \mu$. A $50 \mathrm{~g}$ steak was produced at a cost of $\$ 1.50$ USD, indicating the cost-effectiveness of the fabrication [74,75]. An Israel-based company has also claimed to have fabricated plant-based steaks with plant-based protein, fat, and water. According to a press release, the cost of a $200 \mathrm{~g}$ printed steak was about \$4 USD. Along with beef, they plan to focus on other livestock meat such as tuna and pork [74]. However, it is important to note that the lack of full publically available information may lead to uncertainty about the future of the products, processes, or the company. Nevertheless, inadequate essential amino acids, the necessity of texturization of plant proteins, and the inclusion of various non-proteinaceous ingredients are some of the major hurdles in the development of 3D meat analogs. Furthermore, plant-based analogs are mostly products such as sausages, patties, and mince. The development of steaks from plant-based materials seems to be a difficult undertaking [76]. Nonetheless, in 2017, the idea of an emulsified red meat ink was proposed for the first time by Meat and Livestock Australia during a 3D food printing conference [77]. Recently, another ingredient, mushroom, which resembles meat, was used to 3D print a snack. Printing of fiber-rich food is considered to be a challenge owing to the aggregation of the complex network of fibers, which leads to the clogging of printer nozzles. In this study, although not as a meat analog, it was possible to print 
a snack using mushroom and wheat flour [18]. Thus, meat analogs could be fabricated with mushrooms as a major ingredient. However, sustainable alternatives to plant-derived materials for the development of meat analogs are insects.

\subsection{Alternative Materials: Insect-Derived 3D Structures}

In many countries, insects are consumed as a flavorsome and healthy source of proteins. While the nutritional value of insects is dependent on factors such as species and sex, they are considered to be rich sources of iron, copper, and minerals (Table 5). It is also suggested that insects may be superior to animal meats or plants in terms of their protein levels (50-85\%). Particularly, insect proteins are considered superior to livestock meat protein due to their high digestibility (75-98\%) [78]. As a result, attempts are being made to replace animal-derived proteins with edible insects (e.g., mealworm larvae and adult crickets) on an equal weight basis [79]. The most consumed species of insects in the world are beetles (Coleoptera), which accounts for $31 \%$, followed by moths and butterflies (Lepidoptera) for $18 \%$. About $14 \%$ of worldwide insect consumption comes from ants, bees, and wasps (Hymenoptera) and 13\% from grasshoppers, locusts, and crickets (Orthoptera). Consumption of leafhoppers, cicadas, aphids, and true bugs (Hemiptera), termites (Isoptera), dragonflies (Odonata), and flies (Diptera) is about 10\%, 3\%, 3\%, and 2\%, respectively $[78,80]$. However, owing to the widespread perception that the consumption of insects is the consumption of filth, changing its form has been recommended. To this end, insects have been dried and pulverized into powders and flours, which thereby reduce disgust reaction [81]. Other insect materials that can potentially be used in various fabricated foods are proteins (soluble/insoluble), lipids, and fibers. With respect to proteins, studies have focused on their pH-dependent solubility, emulsion activity, interfacial property, and gelling behavior [28,82]. However, the optimal concentrations of different materials in various combinations on the textural and sensory properties have to be investigated.

Table 5. Some examples of common insects and their characteristics.

\begin{tabular}{|c|c|c|c|c|}
\hline Insect Type & Protein (\%) & Lipid (\%) & Other Nutrients & References \\
\hline Ground cricket & $48-67 \%$ (dry wt) & $\begin{array}{c}5-20 \% \\
\text { (species dependent) }\end{array}$ & $\begin{array}{c}\text { Fiber } 8.7-18 \% \text {, } \\
\text { Vitamin B12, } \\
\text { Fe, } \mathrm{Zn}, \mathrm{Cu}\end{array}$ & {$[83,84]$} \\
\hline Grasshopper & $\begin{array}{l}13-28 \%(\text { fresh wt) } \\
57-69 \% \text { (dry wt); }\end{array}$ & 3-67\% (dry wt) & $\begin{array}{l}\text { Crude fiber } 8.5-12.5 \% \\
\text { Fe, Mn, Cu, Ca, P, Zn }\end{array}$ & {$[83,85]$} \\
\hline Back soldier fly & $40-44 \%$ (dry wt) & $15-49 \%$ (dry wt) & $\begin{array}{c}\text { Crude fiber 7\% (dry wt) } \\
\text { Mn, Zn, Ca, P }\end{array}$ & {$[86,87]$} \\
\hline Weaver ant & $26-48.5 \%$ (dry wt) & $10-25 \%$ (fresh wt) & $\begin{array}{l}\text { Vitamin B1, B2, B3, P, } \\
\mathrm{Mg}, \mathrm{Na}, \mathrm{Zn}, \mathrm{Ca}, \mathrm{Fe}\end{array}$ & [78] \\
\hline Palm Weevil beetle & 7-36\% (fresh wt) & $54 \%$ (dry wt) & Vitamin E & [83-85] \\
\hline
\end{tabular}

Adapted from Sun-Waterhouse et al. [77]. Wt, weight.

In one study, flour derived from dried insects (mealworms, crickets) along with fondant was 3D printed to form icing for cakes [88]. Nevertheless, for meat analogs, insect powders of different particle sizes mixed with materials, such as hydrocolloids (e.g gelatin, guar gum), surimi gel, MSM, and meat flavors have yet to be investigated. In another study, mealworm beetle (Tenebrio molitor) enriched-wheat-based snacks were 3D printed. The addition of mealworm powder (20\%) to wheat flour dough softened the raw 3DP snack and also reduced water loss in the baked 3DP final product [17]. However, when a large amount $(>20 \%)$ of insect powders are used in meat analogs, the effect of increased water evaporation from particles has to be considered. In the case of increased water loss from the product, hydrocolloids such as gelatinized starch can be included. Furthermore, to enhance the printability of insect-based pastes, more than one type (composite) of a natural polymer (e.g., collagen, alginate) can potentially be used. Another possible option is the addition of insect powders to meat paste derived from animal byproducts along with transglutaminase. Furthermore, to improve the organoleptic properties, 3DP insect-based products can be 
smoked, which can give a meat-like aroma to the analogs. This will depend on the type of meat analog because it may have to undergo post-processing steps like frying or boiling. However, the formation of a meat-like aroma was reported in a study, wherein insects were smoked in a hot pan (without oil) instead of a wood stove [89]. While insect-enriched foods have been $3 \mathrm{D}$ printed, reformulated insect-derived products that resemble meat products, such as patties, sausages, or steaks, have yet to be 3D printed. For example, ant-loaded candy or cricket in sour cream can not be considered as a meat analog.

\section{Environmental Sustainability}

Apart from the fabrication of 3D meat analogs that mimic the physical properties of livestock meat products, it is important to consider its sustainability. However, sustainability depends on many factors (Figure 4), which include energy consumption, waste generation, and pollution [90]. To this end, a competitive environmental strategies framework has been recommended. To develop a successful meat analog, a firm or a start-up venture can utilize this framework, which includes (a) low-cost strategies such as reducing investment and operational costs and (b) differentiation strategies such as creating sustainability-based value propositions. Furthermore, investments may focus on (c) efficient organizational processes/activities and (d) the development of superior products for consumers [91]. However, an earlier study identified that 3D printing could be cost-effective with low volumes and high-value sectors, such as medical and aerospace component production [19]. The cost of production in 3DP is mainly contingent upon the equipment (machinery), materials, pre-and post-processing steps, and skilled labor [90]. The requirement of lower amounts of inputs and outputs in high-value sectors can result in lower energy usage and related $\mathrm{CO}_{2}$ emissions [19]. Contrarily, the lack of a positive impact on the environment has been reported in other industries such as 3D printed high-speed gears. Nonetheless, the life cycle assessment (LCA) of 3DP foods has yet to be undertaken. LCA is a technique that analyzes the environmental effects of a product throughout its entire life cycle. Thus, regardless of the manufacturing sector, LCA includes 3D printing and the post-processing steps [90].

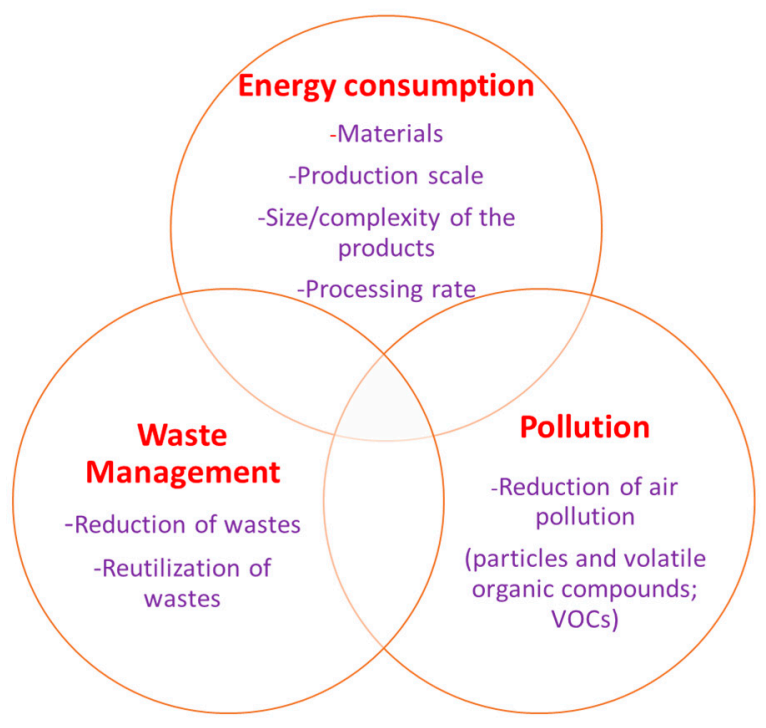

Figure 4. Major facets of the environmental impact of 3D printing (3DP) of meat analogs.

\subsection{Energy Consumption}

Even though it is still under development, the 3D printing of food has been suggested to have the potential to provide many benefits, which include lower amounts of raw materials and energy along with reduced waste [19]. The environmental impacts of 3DP are largely contingent upon the amount of energy consumption-particularly, electrical energy. This form of energy is mainly used in pre-heating the machine and during the printing 
and cooling process. While the energy consumption is similar for samples fabricated with different $3 \mathrm{D}$ printing methods (e.g., additive manufacturing and injection molding), it varies when mass production is involved [90]. Food production is a high-volume business (number/type of products), which also requires a wide array of ingredients in large quantities. Thus, the commercial viability of 3D printers depends on their ability (speed) to print large numbers of products in less time. Energy consumption is also related to the nature of the materials utilized. Materials that require higher temperatures tend to consume more energy and vice versa. For example, tuna-shaped structures are 3D printed using tuna puree with an extrusion system that is pressure-controlled and maintained at $20^{\circ} \mathrm{C}$ [49]. Hummus, cheese, and other such native printable materials are usually extruded at room temperature [16]. It has been reported that many of the food products are printed at room temperature. In addition, 3D-printed, fiber-rich products are required to undergo post-processing treatment such as oven drying for $20-30 \mathrm{~min}$ at $100{ }^{\circ} \mathrm{C}$ [74]. Likewise, products with larger masses also require a higher amount of energy. Thus, due to numerous factors, the evaluation of energy consumption is not an easy undertaking. Furthermore, LCA studies on 3D printing of various types of food products have yet to be undertaken.

The procurement of raw materials (production, distribution, storage) needed for 3DP meat analogs also has an impact on the environment. In the case of in vitro muscle cultivation, LCA studies have suggested that, even though land and inputs required for labgrown meat are less, the energy required for the entire process is significantly higher than livestock meat production [92]. Cell culture is associated with the utilization of electricity and fuel [93]. In one study, although the global warming potential of lab-grown meat was shown to be less than bovine meat, it was found to be not lower than that of porcine or poultry meat. Even though this study had made many assumptions, the industrial scale in vitro biomass culture was found to be energy-intensive [92]. In regards to 3DP of human skeletal muscles for surgical implantations, the muscle constructs undergo a post-processing step that involves perfusion bioreactors, cell encapsulators, and biomonitoring [20]. While these steps improve the functionality of fabricated muscles, they may not be necessary for 3DP of meat analogs, thereby reducing materials, cost, and time.

With respect to insects, farming, or the collection from fields is reported to have a lower environmental impact [94]. While some studies have suggested that insect-derived food is more eco-friendly than livestock meat, information about the environmental impact is very limited. According to an LCA-based study on mealworms (Tenebrio molitor) and super worms (Zophobas morio), although the energy usage (EU) for mealworms (per kg of edible protein) was comparable to porcine meat, it was greater than poultry but lesser than bovine meat. The higher EU was mainly because of the heating that was required for the growth of the worms. To overcome this obstacle, along with smaller larvae, largesized larvae were included that could provide higher meat metabolic heat. However, the major advantages of insect farming over livestock farming include the greater rate of reproduction, efficient feed conversion, and the lack of methane release [95]. Likewise, the re-utilization of meat byproducts and waste is also considered to have a positive influence on the environment. According to an earlier estimate, bovine slaughterhouses generate the highest quantity of solid waste ( $27 \%$ of the animal weight) followed by sheep slaughterhouses ( $17 \%$ of the animal weight) and pig slaughterhouses ( $4 \%$ of the animal weight). Hence, it becomes important to reuse these types of wastes, which otherwise would be dumped in landfills [54]. Commercial and domestic fish wastes are also usually discarded into landfills or into the sea [66]. Similarly, plant/agricultural waste can also be reutilized for the cleaner production of 3D meat analogs. However, the extraction of valuable biomaterials from these types of animal/seafood industrial wastes is also an energy-intensive process.

In this regard, a recent study investigated the extraction of proteins from poultry meat processing waste via mechanical pressing and non-thermal pulsed electric fields. It was reported that the extraction of liquid was improved when non-thermal treatment, which used a low voltage long pulse, was used on wasted chicken breast muscles. This was achieved 
without the need for any chemicals. With an input of total energy of $38.4 \pm 1.2 \mathrm{~J} \mathrm{~g}^{-1}$, extraction of wasted chicken biomass resulted in $\sim 12 \%$ liquid fraction. Additional income, reduced waste, and waste-related environmental impact were some of the benefits reported [95]. Similar to other food production methods, 3DP also generates wastes, which must be eliminated, reduced, and reutilized [90]. However, data pertaining to wastes generated and their impact on the environment are very limited.

\subsection{Air Pollution}

With the increasing use of additive manufacturing in various industries and academics, its effect on air pollution has gained attention. In this regard, desktop 3D printers have been recommended. This will allow consumers to print their own food, thereby revolutionizing the transport sector. Furthermore, the printing of products or components nearer to the location of consumers could also positively affect the environment. Reduced transportation (at least for long distances) of final products is expected to lower $\mathrm{CO}_{2}$ emissions, thereby improving air quality. However, the procurement of input materials (bio-inks, meat byproducts, and insects) can also cause GHG emissions. In a recent study, GHG emissions during black soldier fly (BSF) rearing was quantified. The rearing of BSF, a promising food alternative, caused direct GHG emissions of about $17 \pm 8.6 \mathrm{~g} \mathrm{CO}_{2}$ eq per kg of dry larvae gain. The results indicated the need for improvements in carbon and energy efficiencies [96]. Nonetheless, the type of input materials also impacts the GHG emissions from 3DP of food products. For example, food products can be 3D printed with bio-polymers that require low temperatures. Furthermore, bio-polymers-derived filaments are known to be non-toxic, biodegradable, and relatively less expensive [90]. However, the emissions of sub-micron particles, nanoparticles, and gases from food-based 3D printers have to be evaluated in a clean room. Since 3DP uses electric power, it is possible that an indirect influence could be through reduced $\mathrm{CO}_{2}$ emission as opposed to conventional livestock meat, which results in all three types of GHG emissions $\left(\mathrm{CH}_{4}, \mathrm{~N}_{2} \mathrm{O}\right.$, and $\left.\mathrm{CO}_{2}\right)$. According to a sustainability study, 3D printing technologies can lower 130.5-525.5 Mt of $\mathrm{CO}_{2}$ emissions by 2025 [19]. Furthermore, $\mathrm{CO}_{2}$ emissions caused by electric power usage can be countered with decarbonization [97]. Another advantage of 3DP is reduced labor costs, which may be further reduced for 3D food production. This is because highly skilled workers are not required for 3D food production as compared to other industries (e.g., aerospace, machinery), where highly skilled workers are required [90]. However, some skill levels may be necessary for 3DP food production compared to conventional food production.

\subsection{Sustainable Supply Chain Management (SSCM)}

Owing to the increasing complexity and concerns over the environment, several countries around the world are trying to create and facilitate sustainable supply chains (SSC). It is known that improvement in the sustainability of SSC is contingent upon waste reduction [98]. This is of great importance in both animal- and plant-derived foods. The total amount of global food loss and wastes has been estimated to be nearly 1.3 billion tons annually. Hence, it is important to reduce wastes and loss at different stages of the supply chain [99]. This also applies to the 3D printing of meat analogs. Even in animal cell culture for meat, real-time sensors estimate the number of nutrients and wastes, which in turn lowers operational costs [100]. Another potential source of protein for plant-based meat substitutes is plant waste biomass. In one study, protein derived from peanut biomass waste was used for the production of meat substitutes via high-moisture extrusion [101]. With respect to plant wastes, a wide variety of proteins and fibers can be derived that can be used for the production of meat analogs. The utilization of wastes is cost-effective and environmental friendly [102]. Likewise, meat byproducts and wastes can also be utilized as major ingredients in the development of products that mimic traditional meat foods such as sausages and patties. To this end, 3D printing offers a promising approach for the mitigation of food wastes. Even in the process of 3D printing, it becomes important to reduce wastes. This can be achieved by highly efficient and productive 
printers. Nonetheless, efficiency is dependent on the optimization of all activities along a supply chain that include the rational organization of activities, physical flow of materials, and logistic costs [103]. This becomes very important when 3D printing is scaled up and commercialized. In the case of bioprinting, the development of generic/universal components or scaffolds and optimization in cell sourcing and fabrication logistics will lower production costs [104] and provide sustainability.

\section{Consumer Acceptance}

Apart from deeply entrenched attitudes toward livestock meat, unfamiliarity and ideation are major impediments in the acceptance of several types of meat analogs [102]. Particularly, 3DP brings several types of unfamiliar elements to the food production sector. In a study by Lupton et al. [105], the major elements that influence consumer acceptance of 3DP products were evaluated. According to this study, the novel method of food production that uses digital technology is not understood very well by consumers. Moreover, many of the 3D-printed food products are overtly different from conventional food. In the cases where the printed products mimic conventional products, they are often viewed with suspicion. Furthermore, unfamiliarity with the food is a major hurdle in its acceptance. Printed foods with familiar ingredients, such as chocolate, dough, and sugar, are acceptable by consumers. On the other hand, foods printed with unfamiliar ingredients, such as insects and algae, are unacceptable in western countries. The lack of acceptance can be attributed to the perceived strangeness of the novel foods, a similar response observed with in vitro meat [105]. In a recent study, in regards to the idea of 3DP meat and insect-derived products, most of the respondents considered 3DP food as unnatural, with responses that encompassed being potentially harmful, lacking freshness, not tasting good, or lacking nutritional value. It was also indicated that the consumer acceptance of novel food depends on the knowledge of preparation methods [50]. Moreover, introducing 3D printers to kitchens and the inclusion of ingredients such as insects are major impediments to its acceptance [14]. In a more recent study, consumers' attitudes and their acceptance of 3D printed foods were compared with conventional foods. This online survey of 329 Canadian residents showed that half of the consumers would accept and were excited about 3D-printed foods. Within the recognized three clusters, the markedly interested cluster and the moderately interested cluster were acceptable vies of meatballs and sauce fabricated with 3D printers. They believed that these products were healthy and highly processed, and they would consider buying and eating them. Contrarily, the third cluster (not interested cluster) were less willing to buy or eat and did not consider these products to be healthy or highly processed [106]. However, sensory analysis and consumer opinions of actual 3DP meat analogs derived from muscle cells, meat byproducts, and plant materials in comparison with conventional meat products (livestock derived) have to be investigated. Nonetheless, studies have shown that the adoption of meat analogs by consumers is based on an innovation-decision process. The consumer behavior toward novel foods can be understood using the five different stages of this process: knowledge, persuasion, decision, implementation, and confirmation. In the knowledge stage, it is important the consumer learns many details about the meat analogs that include the formulation method and ingredients. In the persuasion stage, a favorable or an unfavorable opinion or attitude is formed about the product. In the decision stage, the consumer makes a decision to adopt or reject the novel product. During implementation, the consumer adopts and consumes the meat alternative frequently. Finally, in the confirmation stage, the consumer continues to consume the meat substitute or revises decisions. Based on the innovation-decision process for meat substitutes, policy measures, large-scale marketing campaigns, and offering meat alternatives in canteens/cafeterias have been recommended [107]. However, because 3Dprinted meat alternatives are in their initial stages and not well established, the innovationdecision process could improve the understanding of the consumer acceptance of 3Dprinted meat substitutes. 


\section{Future Prospects}

To envision the future of 3D-printed meat analogs, it is important to focus on the technologies involved and the state of meat analogs in the food market [104,107]. By looking at novel products, the factors that influenced their success could be evaluated. While several meat substitutes exist, not even one has been well established (eaten regularly). However, because 3D printing is in its initial stage, research on both materials and printers is required. Food-safe (bioprinting) and insect-derived materials that are suitable for 3D printing of meat analogs have to be explored. The utilization of plant and animal byproducts/wastes for the fabrication of meat analogs could improve its sustainability. Furthermore, the development of printers that are rapid, precise, and productive as well as energy-efficient is required. The sustainability of meat analogs will depend on efficient supply chain management (Farm to fork), which focuses on lowering production costs and environmental impact. Utilizing the innovation-decision process, consumer acceptance of 3D meat analogs could be improved. In particular, policy measures, financial incentives, and large-scale marketing campaigns could have a significant impact.

\section{Conclusions}

Livestock meat production is known to be related to the enormous utilization of land and resources, and large GHG footprint. Researchers have fostered their efforts to substitute livestock meat with other alternatives in order to provide sustainable benefits. Although $3 \mathrm{D}$ printing is suggested to have the capability to reduce wastes, energy, and monitory inputs, its environmental impact has not been studied. For 3DP of meat analogs, materials derived mainly from insects, plants, meat byproducts, and muscle cells are explored from the technological feasibility, environmental impact, and consumer acceptance standpoints. While several materials exist for skeletal muscle printing (bioprinting), only food-safe materials are required for meat analog development. Bioprinting of vascular network may not be required. Sustainability can be improved by utilizing generic/universal components or scaffolds and optimizing cell sourcing and fabrication logistics. Using a wide variety of plant materials, some start-up ventures claimed to have printed meat analogs. To improve the sustainability of $3 \mathrm{D}$ printing, plant byproducts/waste-derived ingredients can be considered. Apart from powders that are formed by milling, proteins (soluble/insoluble), lipids, and fibers can also be produced. At optimal concentrations and different combinations, these materials can potentially be used in meat substitutes. The utilization of meat byproducts and wastes can be cost-effective and environmental friendly, thereby making it sustainable. The fish industry wastes such as skin have been shown to have costrelated advantages. Applying 3DP technology is well suited for the utilization of insects and animal byproducts because their consumption faces perception- related challenges. The utilization of cell cultures and meat byproducts for 3D printing of meat analogs could face regulatory challenges. Environmental impact is related to energy consumption, which in turn is related to the type of printers and materials as well as the weight of the final products. Although animals and large land areas are not required for in vitro cultivation of muscle cells or insect farming, the large-scale production of these meat substitutes is still energy-intensive. While 3D design requirements, low precision, and low productivity are the major demerits of 3DP, the lack of requirement for highly skilled labor is its major merit. Along with the 3DP of meat analogs, LCA-based studies have yet to be conducted. While more studies about consumer acceptance are needed, the lower acceptance of meat analogs is attributed to the perceived strangeness of the 3DP foods. The sustainability of plant- and animal-based food supply chains can be improved via the utilization of wastes by 3D printing. The sustainability of 3D printers can be improved by printer innovations, rational organization of activities, optimization of material flow, and logistic costs. This novel technology is still in its initial phase, and its sustainability implications regarding the large-scale production of meat substitutes have to be assessed. 
Author Contributions: Conceptualization, methodology, software, validation, formal analysis, investigation, resources, data curation, writing—original draft preparation, writing—review and editing, visualization: K.R. All authors have read and agreed to the published version of the manuscript.

Funding: This research received no external funding.

Institutional Review Board Statement: Not applicable.

Informed Consent Statement: Not applicable.

Data Availability Statement: No new data were created or analyzed in this study. Data sharing is not applicable to this article.

Conflicts of Interest: The author declares no conflict of interest.

\section{References}

1. McMichael, A.J.; Powles, J.W.; Butler, C.D.; Uauy, R. Food, livestock production, energy, climate change, and health. Lancet 2007, 370, 1253-1263. [CrossRef]

2. Food and Agriculture Organization of the United Nations (FAO). Climate Change and Food Security: A Framework Document; FAO: Rome, Italy, 2008; Available online: http:/ / www.fao.org/3/k2595e/k2595e00.pdf (accessed on 11 July 2020).

3. Intergovernmental Panel on Climate Change (IPCC). Climate Change and Land: Special Report on Climate Change, Desertification, Land Degradation, Sustainable Land Management, Food Security, and Greenhouse Gas Fluxes in Terrestrial Ecosystems. 2019. Available online: https://www.ipcc.ch/site/assets/uploads/2019/08/4.-SPM_Approved_Microsite_FINAL.pdf (accessed on 12 July 2020).

4. Gerber, P.J.H.; Steinfeld, B.; Henderson, A.; Mottet, C.; Opio, J.; Dijkman, A.; Falcucci, A.; Tempio, G. Tackling Climate Change through Livestock-A Global Assessment of Emissions and Mitigation Opportunities; Food and Agriculture Organization of the United Nations (FAO): Rome, Italy, 2013.

5. Eshel, G.; Shepon, A.; Makov, T.; Milo, R. Land, irrigation water, greenhouse gas, and reactive nitrogen burdens of meat, eggs, and dairy production in the United States. Proc. Natl. Acad. Sci. USA 2014, 111, 11996-12001. [CrossRef] [PubMed]

6. Flachowsky, G.; Kamphues, J. Carbon footprints for food of animal origin: What are the most preferable criteria to measure animal yields? Animals 2012, 2, 108-126. [CrossRef] [PubMed]

7. Jackson, B.; Lee-Woolf, C.; Higginson, F.; Wallace, J.; Agathou, N. Strategies for Reducing the Climate Impacts of Red Meat/Dairy Consumption in the UK; WWF and Imperial College: London, UK, 2009; pp. 1-84.

8. de Bakker, E.; Dagevos, H. Reducing meat consumption in today's consumer society: Questioning the citizen-consumer gap. J. Agric. Environ. Ethics 2012, 25, 877-894. [CrossRef]

9. Springmann, M.; Clark, M.; Mason-D'Croz, D.; Wiebe, K.; Bodirsky, B.L.; Lassaletta, L.; Willett, W. Options for keeping the food system within environmental limits. Nature 2018, 562, 519-525. [CrossRef] [PubMed]

10. Smetana, S.; Mathys, A.; Knoch, A.; Heinz, V. Meat alternatives: Life cycle assessment of most known meat substitutes. Int. J. Life Cycle Assess. 2015, 20, 1254-1267. [CrossRef]

11. Lynch, J.; Pierrehumbert, R. Climate impacts of cultured meat and beef cattle. Front. Sustain. Food Syst. 2019, 3, 5. [CrossRef] [PubMed]

12. Allied, M.R. Meat Substitute Market by Product Type, Source and Category: Global Opportunity Analysis and Industry Forecast, 2018-2025. 2018. Available online: https:/ / www.alliedmarketresearch.com/press-release/global-meat-substitute-market.html (accessed on 13 July 2020).

13. Stephens, N.; Di Silvio, L.; Dunsford, I.; Ellis, M.; Glencross, A.; Sexton, A. Bringing cultured meat to market: Technical, socio-political, and regulatory challenges in cellular agriculture. Trends Food Sci. Technol. 2018, 78, 155-166. [CrossRef] [PubMed]

14. Dick, A.; Bhandari, B.; Prakash, S. 3D printing of meat. Meat Sci. 2019, 153, 35-44. [CrossRef]

15. Godoi, F.C.; Prakash, S.; Bhandari, B.R. 3D printing technologies applied for food design: Status and prospects. J. Food Eng. 2016, 179, 44-54. [CrossRef]

16. Sun, J.; Zhou, W.; Huang, D.; Fuh, J.Y.H.; Hong, G.S. An overview of 3D printing technologies for food fabrication. Food Bioprocess Technol. 2015, 8, 1605-1615. [CrossRef]

17. Severini, C.; Derossi, A.; Ricci, I.; Caporizzi, R.; Fiore, A. Printing a blend of fruit and vegetables. New advances on critical variables and shelf life of 3D edible objects. J. Food Eng. 2018, 220, 89-100. [CrossRef]

18. Keerthana, K.; Anukiruthika, T.; Moses, J.A.; Anandharamakrishnan, C. Development of fiber-enriched 3D printed snacks from alternative foods: A study on button mushroom. J. Food Eng. 2020, 287, 110116. [CrossRef]

19. Gebler, M.; Schoot Uiterkamp, A.J.M.; Visser, C. A global sustainability perspective on 3D printing technologies. Energy Policy 2014, 74, 158-167. [CrossRef]

20. Munaz, A.; Vadivelu, R.K.; St. John, J.; Barton, M.; Kamble, H.; Nguyen, N.-T. Three-dimensional printing of biological matters. J. Sci. Adv. Mater. Devices 2016, 1, 1-17. [CrossRef]

21. Noorani, R. 3D Printing: Technology, Applications, and Selection; CRC Press: Milton, UK, 2017.

22. Garrett, B. 3D Printing: New Economic Paradigms and Strategic Shifts. Glob. Policy 2014, 5, 70-75. [CrossRef] 
23. Min, S.; Ko, I.K.; Yoo, J.J. State-of-the-Art Strategies for the Vascularization of Three-Dimensional Engineered Organs. Vasc. Spec. Int. 2019, 35, 77-89. [CrossRef]

24. Liu, C.; Ho, C.; Wang, J. The development of 3D food printer for printing fibrous meat materials. In Proceedings of the IOP Conference Series: Materials Science and Engineering, 2nd International Conference on Innovative Engineering Materials (ICIEM 2017), Philadelphia, PA, USA, 21-23 October 2017.

25. Dekkers, B.L.; Boom, R.M.; van der Goot, A.J. Structuring processes for meat analogues. Trends Food Sci. Technol. 2018, 81, 25-36. [CrossRef]

26. Lipton, J.; Arnold, D.; Nigl, F.; Lopez, N.; Cohen, D.; Norén, N.; Lipson, H. Multi-material food printing with complex internal structure suitable for conventional post-processing. In Proceedings of the Solid Freeform Fabrication Symposium, Austin, TX, USA, 17-19 August 2010; pp. 809-815.

27. Chen, T.; Lin, Y.-C. Feasibility Evaluation and Optimization of a Smart Manufacturing System Based on 3D Printing: A Review. Int. J. Intell. Syst. 2017, 32, 394-413. [CrossRef]

28. Azzollini, D.; Fogliano, F. Potential and Challenges of Edible Insects in 3D Food Printing. Available online: https: //3dfoodprintingconference.com/wp-content/uploads/2017/07/Domenico-Azzollini-wur.pdf (accessed on 17 July 2020).

29. Caporizzi, R.; Derossi, A.; Severini, C. Cereal-Based and Insect-Enriched Printable Food. In Fundamentals of 3D Food Printing and Applications; Academic Press: Cambridge, MA, USA, 2019; pp. 93-116.

30. Zhang, B.; Gao, L.; Ma, L.; Luo, Y.; Yang, H.; Cui, Z. 3D Bioprinting: A Novel Avenue for Manufacturing Tissues and Organs. Engineering 2019, 5, 777-794. [CrossRef]

31. Hsu, L.; Jiang, X. 'Living' Inks for 3D Bioprinting. Trends Biotechnol. 2019, 37, 795-796. [CrossRef] [PubMed]

32. Food and Agriculture Organization of the United Nations (FAO). Meat Processing Products; FAO: Rome, Italy, 2014; Available online: http:/ / www.fao.org/ag/againfo/themes/en/meat/Processing_product.html (accessed on 18 July 2020).

33. Shahrubudin, N.; Koshy, P.; Alipal, J.; Kadir, M.; Lee, T.C. Challenges of 3D printing technology for manufacturing biomedical products: A case study of Malaysian manufacturing firms. Heliyon 2020, 6, e03734. [CrossRef] [PubMed]

34. Zhuang, P.; An, J.; Chua, C.K.; Tan, L.P. Bioprinting of 3D in vitro skeletal muscle models: A review. Mater. Des. 2020, 193, 108794. [CrossRef]

35. Kim, J.H.; Kim, I.; Seol, Y.; Ko, I.K.; Yoo, J.J.; Atala, A.; Lee, S.J. Neural cell integration into 3D bioprinted skeletal muscle constructs accelerates restoration of muscle function. Nat. Commun. 2020, 11, 1025. [CrossRef] [PubMed]

36. Lee, J.M.; Yeong, W.Y. Design and Printing Strategies in 3D Bioprinting of Cell-Hydrogels: A Review. Adv. Healthc. Mater. 2016, 5 , 2856-2865. [CrossRef] [PubMed]

37. Zhao, L.; Huang, Y.; Du, M. Farm animals for studying muscle development and metabolism: Dual purposes for animal production and human health. Anim. Front. 2019, 9, 21-27. [CrossRef]

38. Kim, J.H.; Seol, Y.; Ko, I.K.; Kang, H.W.; Lee, Y.K.; Yoo, J.J.; Atala, A.; Lee, S.J. 3D Bioprinted Human Skeletal Muscle Constructs for Muscle Function Restoration. Sci. Rep. 2018, 8, 12307. [CrossRef]

39. Kang, H.W.; Lee, S.J.; Ko, I.K.; Kengla, C.; Yoo, J.J.; Atala, A. A 3D bioprinting system to produce human-scale tissue constructs with structural integrity. Nat. Biotechnol. 2016, 34, 312-319. [CrossRef]

40. Post, M.J. 11-Proteins in cultured beef. In Proteins in Food Processing, 2nd ed.; Yada, R.Y., Ed.; Woodhead Publishing: Sawston, UK, 2018; pp. 289-298.

41. Choi, Y.-J.; Jun, Y.-J.; Kim, D.Y.; Yi, H.-G.; Chae, S.-H.; Kang, J.; Cho, D.-W. A 3D cell printed muscle construct with tissue-derived bioink for the treatment of volumetric muscle loss. Biomaterials 2019, 206, 160-169. [CrossRef]

42. García-Lizarribar, A.; Fernández-Garibay, X.; Velasco-Mallorquí, F.; Castaño, A.G.; Samitier, J.; Ramon-Azcon, J. Composite Biomaterials as Long-Lasting Scaffolds for 3D Bioprinting of Highly Aligned Muscle Tissue. Macromol. Biosci. 2018, $18,1800167$. [CrossRef]

43. MacQueen, L.A.; Alver, C.G.; Chantre, C.O.; Ahn, S.; Cera, L.; Gonzalez, G.M.; O'Connor, B.B.; Drennan, D.J.; Peters, M.M.; Motta, S.E.; et al. Muscle tissue engineering in fibrous gelatin: Implications for meat analogs. NPJ Sci. Food $2019,3,20$. [CrossRef] [PubMed]

44. Duan, B.; Hockaday, L.A.; Kang, K.H.; Butcher, J.T. 3D Bio-printing of heterogeneous aortic valve conduits with alginate/gelatin hydrogels. J. Biomed. Mater. Res. Part A 2013, 101, 1255-1264. [CrossRef] [PubMed]

45. Capel, A.J.; Rimington, R.P.; Fleming, J.W.; Player, D.J.; Baker, L.A.; Turner, M.C.; Lewis, M.P. Scalable 3D Printed Molds for Human Tissue Engineered Skeletal Muscle. Front. Bioeng. Biotechnol. 2019, 7, 20. [CrossRef] [PubMed]

46. Li, R.; McCarthy, A.; Zhang, Y.S.; Xie, J. Decorating 3D Printed Scaffolds with Electrospun Nanofiber Segments for Tissue Engineering. Adv. Biosyst. 2019, 3, 1900137. [CrossRef]

47. VanDusen, K.W.; Syverud, B.C.; Williams, M.L.; Lee, J.D.; Larkin, L.M. Engineered skeletal muscle units for repair of volumetric muscle loss in the tibialis anterior muscle of a rat. Tissue Eng Part A 2014, 20, 2920-2930. [CrossRef]

48. Modern Meadow. 2020. Available online: http://www.modernmeadow.com/about-us/ (accessed on 15 June 2020 ).

49. Kouzani, A.Z.; Adams, S.; Whyte, D.J.; Oliver, R.; Hemsley, B.; Palmer, S.; Balandin, S. 3D printing of food for people with swallowing difficulties. KnE Eng. 2017, 2, 23-29. [CrossRef]

50. Lupton, D.; Turner, B. Food of the future? Consumer responses to the idea of 3D-printed meat and insect-based foods. Food Foodways 2018, 26, 269-289. [CrossRef] 
51. Portanguen, S.; Tournayre, P.; Sicard, J.; Astruc, T.; Mirade, P.-S. Toward the design of functional foods and biobased products by 3D printing: A review. Trends Food Sci. Technol. 2019, 86, 188-198. [CrossRef]

52. United Nations (UN). Unece Standard Edible Meat Co-Products; UN: Geneva, Switzerland, 2015.

53. Lynch, S.A.; Mullen, A.M.; O’Neill, E.; Drummond, L.; Álvarez, C. Opportunities and perspectives for utilisation of co-products in the meat industry. Meat Sci. 2018, 144, 62-73. [CrossRef]

54. Jayathilakan, K.; Sultana, K.; Radhakrishna, K.; Bawa, A.S. Utilization of byproducts and waste materials from meat, poultry and fish processing industries: A review. J. Food Sci. Technol. 2012, 49, 278-293. [CrossRef]

55. Hsieh, Y.H.; Ofori, J.A. Blood-derived products for human consumption. Revel. Sci. 2011, 1, 14-21.

56. Kubberød, E.; Ueland, Ø.; Tronstad, A.; Risvik, E. Attitudes towards meat and meat-eating among adolescents in Norway: A qualitative study. Appetite 2002, 38, 53-62. [CrossRef] [PubMed]

57. Stangierski, J.; Baranowska, H.M. The Influence of Heating and Cooling Process on the Water Binding in TransglutaminaseModified Chicken Protein Preparation, Assessed Using Low-Field NMR. Food Bioprocess Technol. 2015, 8, 2359-2367. [CrossRef]

58. Rivera, J.A.; Sebranek, J.G.; Rust, R.E.; Tabatabai, L.B. Composition and protein fractions of different meat by-products used for petfood compared with mechanically separated chicken (MSC). Meat Sci. 2000, 55, 53-59. [CrossRef]

59. Wang, L.; Zhang, M.; Bhandari, B.; Yang, C. Investigation on fish surimi gel as promising food material for 3D printing. J. Food Eng. 2018, 220, 101-108. [CrossRef]

60. Ramachandraiah, K.; Choi, M.-J.; Hong, G.-P. Micro- and nano-scaled materials for strategy-based applications in innovative livestock products: A review. Trends Food Sci. Technol. 2018, 71, 25-35. [CrossRef]

61. Darine, S.; Christophe, V.; Gholamreza, D. Emulsification properties of proteins extracted from beef lungs in the presence of xanthan gum using a continuous rotor/stator system. LWT Food Sci. Technol. 2011, 44, 1179-1188. [CrossRef]

62. Alvarez, C.; Drummond, L.; Mullen, A.M. Protein recovered from meat co-products and processing streams as pork meat replacers in Irish breakfast sausages formulations. LWT Food Sci. Technol. 2018, 96, 679-685. [CrossRef]

63. Toldrá, F.; Reig, M.; Aristoy, M.C.; Mora, L. Generation of bioactive peptides during food processing. Food Chem. 2018, 267, 395-404. [CrossRef]

64. Alao, B.O.; Falowo, A.B.; Chulayo, A.; Muchenje, V. The Potential of Animal By-Products in Food Systems: Production, Prospects and Challenges. Sustainability 2017, 9, 1089. [CrossRef]

65. Nawaz, A.; Li, E.; Irshad, S.; Xiong, Z.; Xiong, H.; Shahbaz, H.M.; Siddique, F. Valorization of fisheries by-products: Challenges and technical concerns to food industry. Trends Food Sci. Technol. 2020, 99, 34-43. [CrossRef]

66. Govindharaj, M.; Roopavath, U.K.; Rath, S.N. Valorization of discarded Marine Eel fish skin for collagen extraction as a 3D printable blue biomaterial for tissue engineering. J. Clean. Prod. 2019, 230, 412-419. [CrossRef]

67. Yang, X.; Lu, Z.; Wu, H.; Li, W.; Zheng, L.; Zhao, J. Collagen-alginate as bioink for three-dimensional (3D) cell printing based cartilage tissue engineering. Mater. Sci. Eng. 2018, 83, 195-201. [CrossRef] [PubMed]

68. Kim, G.; Ahn, S.; Yoon, H.; Kim, Y.; Chun, W. A cryogenic direct-plotting system for fabrication of 3D collagen scaffolds for tissue engineering. J. Mater. Chem. 2009, 19, 8817-8823. [CrossRef]

69. Asgar, M.A.; Fazilah, A.; Huda, N.; Bhat, R.; Karim, A.A. Nonmeat protein alternatives as meat extenders and meat analogs. Compr. Rev. Food Sci. Food Saf. 2010, 9, 513-529. [CrossRef]

70. Vinnari, M. The future of meat consumption-Expert views from Finland. Technol. Forecast. Soc. Chang. 2008, 75, 893-904. [CrossRef]

71. Bohrer, B.M. An investigation of the formulation and nutritional composition of modern meat analogue products. Food Sci. Hum. Wellness 2019, 8, 320-329. [CrossRef]

72. Kyriakopoulou, K.; Dekkers, B.; van der Goot, A.J. Chapter 6-Plant-based meat analogues. In Sustainable Meat Production and Processing; Galanakis, C.M., Ed.; Academic Press: Cambridge, MA, USA, 2019; pp. 103-126.

73. Lille, M.; Nurmela, A.; Nordlund, E.; Metsä-Kortelainen, S.; Sozer, N. Applicability of protein and fiber-rich food materials in extrusion-based 3D printing. J. Food Eng. 2018, 220, 20-27. [CrossRef]

74. Bloomberg. 2019. Available online: https://www.bloomberg.com/news/articles/2019-11-22/fake-meat-companies-are-racingto-3d-print-steaks (accessed on 10 June 2020).

75. NOVAMEAT. Plant based meat. 2020. Available online: https://www.novameat.com/ (accessed on 11 June 2020).

76. Ismail, I.; Hwang, Y.H.; Joo, S.T. Meat analog as future food: A review. J. Anim. Sci. Technol. 2020, 62, 111-120. [CrossRef]

77. Meat, Livestock Australia. 3D Printed Food Conference- MLA Introducing Potential High Valued Red Meat Opportunities/Trends. 2017. Available online: https://www.mla.com.au/research-and-development/search-rd-reports/final-reportdetails/3D-printed-Food-conference-MLA-introducing-potential-high-valued-red-meat-opportunities-trends/3622\# (accessed on 17 July 2020).

78. Sun-Waterhouse, D.; Waterhouse, G.I.N.; You, L.; Zhang, J.; Liu, Y.; Ma, L.; Dong, Y. Transforming insect biomass into consumer wellness foods: A review. Food Res. Int. 2016, 89, 129-151. [CrossRef]

79. Alexander, P.; Brown, C.; Arneth, A.; Dias, C.; Finnigan, J.; Moran, D.; Rounsevell, M.D.A. Could consumption of insects, cultured meat or imitation meat reduce global agricultural land use? Glob. Food Secur. 2017, 15, 22-32. [CrossRef]

80. Jongema, Y. List of Edible Insects of the World. 2017. Available online: https://www.wur.nl/en/Research-Results/Chair-groups/ Plant-Sciences/Laboratory-of-Entomology/Edible-insects/Worldwide-species-list.htm. (accessed on 30 June 2020).

81. Melgar-Lalanne, G.; Hernández-Álvarez, A.J.; Salinas-Castro, A. Edible insects processing. Traditional and innovative technologies. Compr. Rev. Food Sci. Food Saf. 2019, 18, 1166-1191. [CrossRef] [PubMed] 
82. Azzollini, D.; Wibisaphira, T.; Lakemond, C.M.M.; Fogliano, V. Toward the design of insect-based meat analogue: The role of calcium and temperature in coagulation behavior of Alphitobius diaperinus proteins. LWT 2019, 100, 75-82. [CrossRef]

83. Food and Agriculture Organization of the United Nations (FAO). Composition Database for Biodiversity Version 2; BioFoodComp2. (Latest Update: 06 August 2014); FAO: Rome, Italy, 2012; Available online: http:/ / www.fao.org/docrep/017/ap814e/ap814e.pdf (accessed on 15 September 2020).

84. Bukkens, S.G.F. Insects in Human Diet: Nutritional Aspects. In Ecological Implications of Minilivestock, Role of Rodents, Frogs, Snails, and Insects for Sustainable Development; Paoletti, M.G., Ed.; Science Publishers: Enfield, NH, USA, 2005; pp. 545-577.

85. Womeni, H.M.; Linder, M.; Tiencheu, B.; Mbiapo, F.T.; Villeneuve, P.; Fanni, J.; Parmentier, M. Oils of insects and larvae consumed in Africa: Potential sources of polyunsaturated fatty acids. OCL 2009, 16, 230-235. [CrossRef]

86. Arango Gutiérrez, G.P.; Vergara Ruiz, R.A.; Mejía Vélez, H. Analisis composicional, microbiológico y digestibilidad de la proteína de la harina de larvas de hermetia illuscens 1 (diptera:stratiomyiidae) en angelópolis-antioquia, colombia. Rev. Fac. Nac. Agron. Medellín 2004, 57, 2491-2500.

87. Newton, L.; Sheppard, C.; Watson, D.W.; Burtle, G.; Dove, R. Using the Black Soldier Fly, Hermetia illucens, As a Value-Added Tool for the Managementof Swine Manure; Report for Mike Williams; Director of the Animal and Poultry Waste Management Center, North Carolina State University: Raleigh, NC, USA, 2005.

88. Soares, S.; Forkes, A. Insects Au Gratin-An Investigation into the Experiences of Developing a 3D Printer that uses Insect Protein Based Flour as a Building Medium for the Production of Sustainable Food. In Proceedings of the 16th International Conference on Engineering and Product Design Education, London South Bank University, Enschede, The Netherlands, 4-5 September 2014; Bohemia, E., Eger, A., Eggink, W., Kovacevic, A., Parkinson, B., Wits, W., Eds.; The Design Society: Glasgow, UK, 2014; pp. 426-431.

89. Fombong, F.T.; Van Der Borght, M.; Vanden Broeck, J. Influence of freeze-drying and oven-drying post blanching on the nutrient composition of the edible insect Ruspolia differens. Insects 2017, 8, 102. [CrossRef]

90. Khosravani, M.R.; Reinicke, T. On the environmental impacts of 3D printing technology. Appl. Mater. Today 2020, 20, 100689. [CrossRef]

91. Reis, G.G.; Heidemann, M.S.; Matos, K.H.O.D.; Molento, C.F.M. Cell-Based Meat and Firms' Environmental Strategies: New Rationales as per Available Literature. Sustainability 2020, 12, 9418. [CrossRef]

92. Mattick, C.S.; Landis, A.E.; Allenby, B.R.; Genovese, N.J. Anticipatory life cycle analysis of in vitro biomass cultivation for cultured meat production in the United States. Environ. Sci. Technol. 2015, 49, 11941-11949. [CrossRef]

93. Tuomisto, H.L.; Teixeira de Mattos, M.J. Environmental Impacts of Cultured Meat Production. Environ. Sci. Technol. 2011, 45, 6117-6123. [CrossRef]

94. Oonincx, D.G.A.B.; de Boer, I.J.M. Environmental impact of the production of mealworms as a protein source for humans-A life cycle assessment. PLoS ONE 2012, 7, e51145. [CrossRef] [PubMed]

95. Ghosh, S.; Gillis, A.; Sheviryov, J.; Levkov, K.; Golberg, A. Towards waste meat biorefinery: Extraction of proteins from waste chicken meat with non-thermal pulsed electric fields and mechanical pressing. J. Clean. Prod. 2019, 208, 220-231. [CrossRef]

96. Parodi, A.; De Boer, I.J.M.; Gerrits, W.J.J.; Van Loon, J.J.A.; Heetkamp, M.J.W.; Van Schelt, J.; Van Zanten, H.H.E. Bioconversion efficiencies, greenhouse gas and ammonia emissions during black soldier fly rearing-A mass balance approach. J. Clean. Prod. 2020, 271, 122488. [CrossRef]

97. Ritchie, H.; Reay, D.S.; Higgins, P. Potential of meat substitutes for climate change mitigation and improved human health in high-income markets. Front. Sustain. Food Syst. 2018, 2, 16. [CrossRef]

98. Kaipia, R.; Dukovska-Popovska, I.; Loikkanen, L. Creating sustainable fresh food supply chains through waste reduction. Int. J. Phys. Distrib. Logist. Manag. 2013, 43, 262-276. [CrossRef]

99. Qiu, F.; Hu, Q.; Xu, B. Fresh Agricultural Products Supply Chain Coordination and Volume Loss Reduction Based on Strategic Consumer. Int. J. Environ. Res. Public Health 2020, 17, 7915. [CrossRef] [PubMed]

100. Choudhury, D.; Tseng, T.W.; Swartz, E. The Business of Cultured Meat. Trends Biotechnol. 2020, 38, 573-577. [CrossRef]

101. Zhang, J.; Liu, L.; Jiang, Y.; Faisal, S.; Wei, L.; Cao, C.; Wang, Q. Converting Peanut Protein Biomass Waste into “Double Green” Meat Substitutes Using a High-Moisture Extrusion Process: A Multiscale Method to Explore a Process for Forming a Meat-Like Fibrous Structure. J. Agric. Food Chem. 2019, 67, 10713-10725. [CrossRef]

102. Jiang, G.; Ameer, K.; Kim, H.; Lee, E.-J.; Ramachandraiah, K.; Hong, G.-P. Strategies for Sustainable Substitution of Livestock Meat. Foods 2020, 9, 1227. [CrossRef]

103. Zimon, D.; Madzik, P.; Domingues, P. Development of Key Processes along the Supply Chain by Implementing the ISO 22000 Standard. Sustainability 2020, 12, 61. [CrossRef]

104. Murphy, S.V.; De Coppi, P.; Atala, A. Opportunities and challenges of translational 3D bioprinting. Nat. Biomed. Eng. 2020, 4, 370-380. [CrossRef] [PubMed]

105. Lupton, D.; Bethaney, T. Both Fascinating and Disturbing: Consumer Responses to 3D Food Printing and Implications for Food Activism. In Digital Food Activism; Schneider, T., Ed.; Routledge: London, UK, 2018; pp. 151-167.

106. Manstan, T.; McSweeney, M.B. Consumers' attitudes towards and acceptance of 3D printed foods in comparison with conventional food products. Int. J. Food Sci. Technol. 2020, 55, 323-331. [CrossRef]

107. Weinrich, R. Opportunities for the Adoption of Health-Based Sustainable Dietary Patterns: A Review on Consumer Research of Meat Substitutes. Sustainability 2019, 11, 4028. [CrossRef] 